\title{
MORALIDADE, DIREITOS HUMANOS E PROPRIEDADE PRIVADA
}

\author{
MORALITY, HUMAN RIGHTS AND PRIVATE PROPERTY
}

Enoque Feitosa*

Recebido em: 02/2018

Aprovado em: 03/2018

\begin{abstract}
Resumo: O problema teórico e prático acerca de saber se é possível uma fundamentação filosófica universalista de alguns direitos é um problema crucial no debate acerca do status gnosiológico, axiológico e ontológico desse campo da ética positiva que é o direito. Este texto pretende examinar e criticar as concepções que defendem a apropriação privada das riquezas resultantes do trabalho social enquanto direito humano fundamental, notadamente em face da apologia ao egoísmo, típico da cultura burguesa, ignorando que tanto ele quanto a abnegação são formas pessoais da luta pela sobrevivência e que, em regra, caracteriza a defesa desse ponto de vista.
\end{abstract}

Palavras-chave: Direitos. Propriedade privada. Direitos humanos fundamentais.

\begin{abstract}
The theoretical and practical problem of knowing if an universalist philosophical foundation of some rights is possible is a crucial problem in the debate about the gnosiological, axiological, and ontological status of this field of positive ethics, which is law. This text seeks to examine and criticize the conceptions that defend the private appropriation of the riches resulting from social work as a fundamental human right, especially in the face of the apology to egoism, typical of bourgeois culture, ignoring that both he and self-denial are personal forms of struggle for and, as a rule, characterizes the defense of that point of view.
\end{abstract}

Keywords: Rights. Private property. Fundamental human rights.

\section{Introdução: concepção privatista dos Direitos Humanos e a crítica marxista}

A questão de se é possível uma fundamentação filosófica universalista de alguns direitos é um problema crucial no debate acerca do status gnosiológico, axiológico e ontológico desse campo da ética positiva que é o direito.

Nesse tocante, e pelos motivos que serão examinados neste artigo, é um problema crucial, criticar as concepções que defendem a apropriação privada das riquezas resultantes do

\footnotetext{
* Professor associado da UFPB, lecionando nos Programas de Pós-Graduação em Direito e em Filosofia. Doutor em Direito e em Filosofia.
} 
trabalho social enquanto direito humano fundamental, notadamente em face da apologia ao egoísmo, típico da cultura burguesa, ignorando que tanto ele quanto a abnegação são formas pessoais da luta pela sobrevivência ${ }^{1}$ e que, em regra, caracteriza a defesa desse ponto de vista.

Por algum tempo foi erigido, e de certa forma ainda o é, quase que como um tabu na reflexão jus-filosófica sobre a propriedade privada definir o status ontológico da mesma e de saber como ela é fundamentada internamente por cada ordem jurídica ou se é sua existência é resultante apenas do poder material e ideológico, encoberto por um discurso de justificação político, religioso (ou ambos). Encetar tal crítica não é patrimônio exclusivo da cultura marxista visto que mesmo algum daqueles que não podem ser acusados de qualquer simpatia pelo marxismo reconhecem que a abordagem das consequências práticas das raízes históricas do egoísmo não pode deixar de levar em conta que ela está intrinsecamente relacionada à exacerbação ao limite não da preocupação com determinados interesses individuais e sim com o individualismo mais rasteiro.

Tal modo, ao tempo em que supervaloriza o individualismo, é a mais radical negação do indivíduo na medida em que o vê não como pessoa e sim como uma fonte geradora de riqueza, subsumindo a tudo e a todos ao interesse próprio, isto é, egoístico, "eliminando o problema moral da ação humana", estimulando a ideia pela qual "não há mais problema moral porque não há conflito de interesses", ou seja, defendendo que há apenas um interesse e este é o interesse privado em total contraposição aos interesses coletivos. ${ }^{2}$

Ou seja, trata-se de saber se esse direito tem uma validade independentemente do tempo e do lugar (isto é, se é um direito "natural") e se ela (a propriedade privada) quer, discursivamente, funcionar na forma de uma moralidade atemporal, universal, válida da mesma forma quaisquer que sejam suas prescrições, para todos os tempos, culturas e lugares ${ }^{3}$. Se for defendida enquanto um suposto direito natural "dos de cima", não custa lembrar a prudente advertência de Marx, pela qual

I do not intend discussing here all the arguments put forward by the advocates

\footnotetext{
${ }^{1}$ MARX, K; ENGELS, F. German ideology. In: Marx \& Engels Collected works, vol.5 (Marx and Engels 1845 47). London: Lawrence and Wishart, 2010, p. 273.

2 As afirmações entre aspas são de: LUX, K. Adam Smith's mistake: How a moral philosopher invented Economics and endend morality. Boston: Shambhala Publications, 1990, cap. 4.

${ }^{3}$ Alguns estudiosos colocam o problema no sentido de que a fundamentação e legitimação dos direitos humanos - afirmação com a qual concordamos plenamente - é situacional, sob pena de se cair numa fundamentação do direito pelo direito, que é, a nosso ver, a estratégia ideológica de ocultação do caráter e da natureza do próprio direito. Para a abordagem situacional ver: MARSILAC, Narbal de. A relegitimação da retórica e os direitos fundamentais do homem. In: Verba Júris (Anuário da Pós-Graduação em Direito), ano 7, nº 7. João Pessoa: UFPB / CCJ / PPGCJ, 2008, p. 35-52, especialmente p. 43.
} 
of private property in land, by jurists, philosophers and political economists, but shall confine myself firstly to state that they have tried hard to disguise the primitive fact of conquest under the cloak of "Natural Right". If conquest constituted a natural right on the part of the few, the many have only to gather sufficient strength in order to acquire the natural right of reconquering what has been taken from them ${ }^{4}$.

Mas, para o saber oficial, cuja tônica é olhar o direito por um viés de mera análise econômica de custos e benefícios ${ }^{5}$, tal tipo de argumento ou mesmo todo olhar ou crítica externa ao direito não teria a dignidade de uma ciência, sendo tão só ideologia e jamais equiparado à crítica interna, cujo mérito consistiria em lidar com os institutos dogmáticos, aceitando-os como dados prévios, isto é, pressupostos indiscutíveis para poder examinar a forma jurídica e, assim, mais apta a instaurar uma compreensão exata do seu objeto.

Um estudioso do porte de Bobbio, sempre buscou se diferenciar no interior desse debate, não só acerca dessa visão a-histórica do direito, como o fez também acerca da contribuição de Marx à compreensão do universo jurídico. Para ele, ao exame da crítica de Marx à forma jurídica, se não havia em Marx uma teoria do direito, isto não era uma objeção para não refletir sobre suas contribuições a esse campo do saber, visto que o conjunto de sua análise implicava numa "teoria sociológica do direito in nuce". 6

O que se ignora, em quaisquer das formas com que a crítica se apresente - ou a do senso comum jurídico ou uma crítica de nível, como promove Bobbio -, é que Marx, defendendo a extinção, (que é um processo gradativo e, por isso, se diferencia de supressão, que é imediato) da forma jurídica e a abolição da propriedade privada, não teria por que elaborar uma teoria do direito e sim empreender a formulação da superação dessa esfera parcial da sociabilidade humana que deve ser contingente e não, como pretendem alguns, universal.

$\mathrm{O}$ direito perde inteligibilidade se visto enquanto dotado de uma historicidade autônoma

\footnotetext{
4 "Não se trata de discutir todos os argumentos levantados pelos advogados da propriedade privada da terra, por juristas, filósofos e economistas. Trata-se de declarar que eles, antes de qualquer coisa se esforçam em disfarçar o fato primitivo da conquista, através do manto diáfano do 'direito natural'. Ora, se a conquista se constituiu num direito natural da minoria, basta então que a maioria reúna força suficiente para adquirir o direito natural de reconquistar o que lhe foi tirado" (Tradução livre minha). MARX, Karl. The nationalisation of the land. In: Marx and Engels Collected Works. London: Lawrence \& Wishart, 2010, p. 131, vol. 23. Este artigo de Marx foi originalmente publicado no 'The international Herald, $\mathrm{n}^{\circ} 2,15.06 .1872$. Foi escrito entre março-abril do mesmo ano.

${ }^{5}$ Para uma análise desse tipo, ver: COSSÍO DIAZ, José Ramon. Derecho y análisis económico. Mexico: FCE, 2001, pp. 225, 247.

${ }^{6}$ BOBBIO, Norberto. Marx e a teoria do direito. In: Nem com Marx, nem contra Marx. São Paulo: UNESP, 2006, p. 207, 219. Entre os autores nacionais, a inexistência de uma teoria do direito em Marx pode ser encontrada em: LYRA FILHO, Roberto. Karl, meu amigo: Diálogo com Marx sobre o direito. Porto Alegre: SAFE / IARS, 1983, p. 11-12, 17, 21-22, 25, 30, 38, 41-42.
} 
em relação ao processo da sociabilidade ${ }^{7}$. Assim, resta saber, e disso que aqui se trata, de saber se o direito de propriedade privada enquanto ele que se opõe erga omnnes ao direito de toda coletividade não apenas deve ocupar lugar primeiro no elenco de direitos humanos ou ocupar posto especial numa concepção de direito.

Tratar o direito, que é, claramente, uma relação social, só se concebe - numa concepção que se reivindique marxista - encarando-o como fenômeno político, histórico, societal e, consequentemente, vendo-o como uma prática em constante diálogo com outros saberes. Para tanto, a primeira tarefa consiste em criticar modelos que o idealizam, afastam da vida social e tentam caracterizar o direito como algo fora e acima das classes, neutro e supostamente desinteressado quanto aos conflitos humanos com os quais lida, evidenciando-as ou enquanto perspectiva ingênua ou como mera abordagem / discurso ideológico claramente compromissado em difundir uma imagem invertida do que de fato é a forma jurídica.

A objeção, geralmente levantada, que o direito é neutro em razão do princípio da imparcialidade do juiz é uma falácia visto que não se confunde uma coisa com outra. O exame racional de qualquer problema pede ponderação e não neutralidade visto que ninguém, para julgar, abdica de crenças, formação e outros valores como quem muda de roupa.

Como lembra Marx, é tola e absurda a pretensão de que o juiz seja imparcial, quando o legislador não o é. Para ele, a imparcialidade é só a forma, nunca o conteúdo do direito. Ademais, nunca é ocioso lembrar, toda forma é sempre forma de um conteúdo ${ }^{8}$.

Com a crescente afirmação do que se chama direitos sociais ganha relevância não só a inserção de tal problemática num conjunto de políticas públicas que visem promovê-los, mas, fundamentalmente, a demanda de diversos setores sociais por sua concretização, visto que não basta a sua existência formal para que eles possam gozar de eficácia. Ora é o aspecto da concretização e a definição de quais são os direitos humanos a serem reivindicados que conduz a necessidade de levar em conta as visões que criticam alguns dos fundamentos desses direitos, notadamente com aquela que promove uma crítica radical às visões particularistas e individualistas acerca dos mesmos, do qual a apropriação privada do trabalho social é uma expressão concentrada. Daí a importância da crítica de Marx, algo que mesmo em desacordo

\footnotetext{
${ }^{7}$ Fato comentado, ainda que incidentalmente, por Marx e Engels, quando afirmam que "não há história da política, do direito, da ciência, da arte, da religião etc.". Ver: MARX, Karl; ENGELS, Friedrich. A ideologia Alemã. São Paulo: Boitempo, 2007, p. 77-78. Esta frase, que pode conduzir a grandes mal-entendidos acerca de um suposto "caráter universal" do direito, apenas aponta que o fundamento do direito não repousa em si mesmo. Sobre o tema ver: NAVES, Márcio. Direito e transição socialista. In: Práxis. Ano 4, nº. 10. Belo Horizonte: Projeto, 1997, p. 61.

${ }^{8}$ MARX, Carlos. La ley sobre los robos de leña. In: Escritos de juventud. México: FCE, 1987, p. 281-282.
} 
(ainda que reconhecesse parcialmente a correção da crítica, mas, contraditoriamente, não a achasse aceitável!) ${ }^{9}$, um pensador liberal, Bobbio, fez questão de dialogar.

No contexto atual, de um Estado Democrático de Direito - visto que todo Estado é "Estado de direito", expressão que afigura um pleonasmo gritante - a discussão acerca dos direitos vive a possibilidade concreta de absorver o conjunto das formulações que lidam com sua problemática pelo viés de um caráter fundamentalmente social. Entretanto, para que isso ocorra, é preciso se dar um passo adiante no sentido de também lidarmos, sem preconceitos, com os estudos que criticam a concepção liberal-individualista dos direitos humanos.

E isso pelo fato de que, quando se busca debater sua concretização dos direitos sociais (que custam, em geral, muito dinheiro) muitas vezes os aparentes consensos pelos quais os direitos devem ser estendidos a todos (ainda que o direito de propriedade privada se opõe à todos que não tem propriedade alguma) se esvai por razões que se examinarão no próximo ponto, a principal delas é que tais direitos, como o direito em geral, é uma construção histórica, social, dependente do espaço, do tempo e da cultura.

Assim, o que aqui se propõe, a partir de agora, abordar os aportes da crítica marxista à concepção liberal-privatista-individualista de direitos humanos, concepção esta oriunda das revoluções burguesas do século XIX, que, em razão da correlação política então existente, erigiu sua concepção de direitos enquanto garantias do indivíduo egoísta e em contradição permanente com os interesses da sociedade.

Em 1791, quando se estavam proclamando, "confiadamente", os direitos do homem, as aspirações primogênitas da revolução francesa, "que nunca haviam de se materializar, já continham uma dose considerável de reivindicações burguesas" e, na declaração dos direitos do homem e do cidadão, "a propriedade ocupava um lugar destacado em quatro dos chamados direitos inalienáveis do homem”. Por isso, “Marx distinguiu, radicalmente, o conteúdo egoísta dos direitos do homem, em seu texto originário, da imagem política, abstrata e idealista, do cidadão".10

Destaque-se que essa discussão já na época avultava em importância pelo fato - nem sempre percebido pelos que formulam modelos para uma teoria sobre fundamentação/ justificação dos direitos humanos - de que a única forma de negar o caráter contextual, temporal, relativos, enfim, dos mesmos, obrigaria, teoricamente, a afirmá-los como dotados de um

\footnotetext{
${ }^{9}$ Esse desacordo está explicitado, por exemplo, em: BOBBIO, Norberto. A era dos direitos. Rio de Janeiro: Elsevier, 2004, p. 111-113.

${ }^{10}$ BLOCH, Ernst. El hombre y el ciudadano según Marx. In: Humanismo socialista. Buenos Aires: Paidós, 1974, p. 242-243.
} 
fundamento prévio, independente da história e acima dos humanos, portanto resgatando uma concepção jusnaturalista, de direito, de moralidade positiva e da moralidade normativa - que da mesma forma que todo essencialismo, pode fundamentar tanto o bem quanto as piores atrocidades.

Ademais, essa visão essencialista, na qual o modelo jusnaturalista se insere independentemente das boas intenções de seus formuladores, imobiliza a luta pela transformação das relações sociais, das quais a forma jurídica é uma das expressões, na medida em que têm em comum o fato de defender um fundamento anterior e superior para o direito existente, com o que se desobrigaria da tarefa de se autojustificar. Por isso a crítica marxista ao jurídico (da mesma forma que a crítica a moral como algo acima e fora das classes) situa aquele campo como fenômeno histórico e enceta a objeção às ideias de um fundamento suprapositivo para o direito no que é contraditado pela concepção liberal, como se verá a seguir.

\section{A crítica liberal à visão marxista sobre os Direitos Humanos}

Em razão da crítica contundente que fez, já num dos textos da juventude - momento da produção teórica de Marx sobre a qual é comum afirmar-se que era marcada por forte crença no direito e na racionalidade moderna - costuma se dizer que aí tínhamos um Marx filosófico, tolerante e democrata, em oposição ao "velho Marx”, ontologicamente rígido e dogmático. Não notam esses críticos mal-avisados que é o Marx jovem e filosófico que produz - no texto "A questão Judaica" - a crítica mais dura a concepção liberal e individualista sobre os direitos humanos. Direitos estes que ele caracteriza enquanto "outra coisa senão os direitos do membro da sociedade burguesa, do homem egoísta, do homem separado do homem e da comunidade"11. Seria então esta uma crítica de um sectário e movido pelos preconceitos, de um democrata radical, contra o direito e uma de suas manifestações, a propriedade privada?

Que a crítica contida - e não apenas na "Questão Judaica" - não se constituía num radicalismo vazio deixou claro (ainda que não fosse esta sua intenção), quase cem anos depois, Hans Kelsen, na sua Teoria Pura do Direito, quando, a propósito de examinar a questão do "sujeito jurídico", isto é, do sujeito de direito, ele observa, criticando as teorias tradicionais (direitos subjetivos como faculdade de agir, como interesse juridicamente protegido, como exercício do poder da vontade) que:

${ }^{11}$ MARX, Karl. Para a questão Judaica. São Paulo: Expressão Popular, 2009, p. 63. 
O conceito de sujeito de direito como portador de direito subjetivo é aqui, no fundo, apenas uma outra forma deste conceito que, no fundamental, foi talhado pela noção de propriedade. (...) A função ideológica desta conceituação de sujeito jurídico como suporte de direitos subjetivos é fácil de penetrar: serve para manter a ideia de que a existência do sujeito de direito como portador de direito subjetivo, quer dizer, da propriedade privada, seria uma categoria transcendente. (...) A ideia de um direito objetivo como portador de um direito subjetivo tem por função defender a instituição da propriedade privada e a sua manutenção permanente pela ordem jurídica. ${ }^{12}$

Desnecessário é dizer que Kelsen não está a criticar as teorias tradicionais pelo fato delas fundamentarem o direito de propriedade e sim por que o fazem de forma teoricamente insuficiente, mas o fato é que ele acaba por, ainda que inconscientemente ou não, não é o caso aqui discutir isso - com essa crítica - demolindo um dos pilares que permitiria a inclusão do direito à propriedade enquanto direito subjetivo.

O motivo pelo qual Bobbio, um positivista analítico - portanto, da mesma forma que Herbert Hart ${ }^{13}$, Alf Ross ${ }^{14}$ e outros, um herdeiro do normativismo kelseniano - não se atentou para isto tem a ver com a sua defesa, jurídica e política, do pleonástico "Estado de Direito" (já que, como se assinalou mais atrás, todo estado é de direito, dado que um não existe sem outro, diferentemente da expressão "Estado democrático de direito" que, mesmo preservando o pleonasmo, evidencia a opção política pelo poder da maioria).

Sabemos que Marx encetou uma crítica de princípio tanto à forma jurídica quanto a moral se entendidas como moral "geral". ${ }^{15}$ Mas, o que isto significaria? Uma renúncia ou recusa a qualquer reivindicação acerca do direito e da moral? A resposta a estas questões é, em ambas, pela negativa. Pelas partes de sua obra onde trata de questões jurídicas, notadamente, nos textos da primeira fase, fica patente sua consciência acerca da importância das reivindicações democráticas, portanto no campo onde existem e atuam relações de Estado e de poder (até pelas raízes etimológicas e históricas do termo "democracia") e, consequentemente, de direito.

E sua crítica ao direito burguês, direito moderno por excelência, do qual a reivindicação

\footnotetext{
12 KELSEN, Hans. Teoria pura do direito. Lisboa: Armênio Amado, 1979, p. 188-191.

13 HART, Herbert. O conceito de direito. Lisboa: Calouste Gulbenkian, 2005. Embora critique alguns dos pressupostos de Kelsen, a filiação de Hart ao campo positivista é induvidosa. Ver, por exemplo, p. 201 ss., onde confronta as concepções do direito natural e do positivismo jurídico.

${ }^{14}$ ROSS, Alf. Direito e Justiça. São Paulo: Edipro, 2007, especialmente p. 53 ss, onde trata do conceito de "direito vigente".

15 "Religião, família, Estado, direito, moral, são apenas formas particulares da produção e caem sob sua lei geral". MARK, Karl. Manuscritos econômico-filosóficos. São Paulo: Boitempo, 2005, p. 106.
} 
ao direito de propriedade privada é expressão, não se situa apenas em A questão Judaica, embora este seja o texto mais citado da polêmica. Essa crítica se encontra presente em $A$ sagrada família, uma polêmica contra Bruno Bauer e consortes, onde segue a polêmica iniciada na A Questão Judaica, acerca do direito; nos Grundrisse, onde em várias partes se reflete sobre a liberdade e igualdade na sociedade burguesa; em "O capital", onde mostra, quando discute a mercadoria, o direito como terreno de regulação do intercâmbio de equivalentes e na Crítica ao Programa de Gotha, onde caracteriza todo direito como direito da desigualdade ${ }^{16}$, evidenciando que o fundamento da crítica à forma jurídica é o mesmo da moral, com a diferença essencial de que, enquanto defendia a supressão do direito na sociedade comunista, ele não pleiteou o mesmo em relação à moral, visto que todo e qualquer agrupamento humano constitui sua visão própria da moralidade.

Trata-se então de desenvolver um diálogo com as concepções que criticam os direitos humanos enquanto algo centrado notadamente na defesa da propriedade privada dos meios de produção. E ter clareza disso é importante, notadamente, para qualquer um que aspire aprofundá-los de tal forma e tão amplamente que os torne desnecessários por que plenamente realizados. Com isso é preciso que se diga que, se há em Marx uma crítica de princípio essa crítica se dirige à forma jurídica enquanto tal. E como já foi destacado, o ponto embaraçoso para a teoria liberal é que Marx rejeita, enfaticamente, a concepção de que o direito à propriedade privada constitui a base moral de todos os direitos humanos.

Para a visão liberal, uma vez que Marx quer extinguir o direito à apropriação privada dos meios de produção, ele é um agressor, um inimigo jurado de todos e quaisquer direitos humanos ${ }^{17}$. Óbvio que para essa teoria liberal é indiferente, para criticar Marx, que a depender da etapa de desenvolvimento social, a luta por reivindicações jurídicas faz todo sentido. A declaração dos direitos do homem e do cidadão, aprovada pela Convenção Nacional, em 1793 e afixada no lugar de suas reuniões, o documento mais radical para àquela época e que prescrevia em seus dois primeiros artigos que os homens [era essa a fórmula de então] tinham

\footnotetext{
${ }^{16}$ MARX, Karl. A sagrada família. São Paulo: Boitempo, 2003, p. 44, 113-115, 128, 202, 214; Grundrisse: Elementos fundamentales para la crítica de la economía política. México: siglo XXI, 1989 ( ( $^{\circ}$ vol.), p. 184, 249, 419, 431; O capital. São Paulo: Abril Cultural, 1983 ( $1^{\circ}$ vol.), p. 61-62, 77, 79, 80, 83-84, 224, 226 ss; Crítica ao Programa de Gotha. São Paulo: ES, 1977, p. 223-243. Ver também: Escritos de juventud. México: FCE, 1987, especialmente os textos: Crítica ao manifesto da escola histórica do direito; Sobre liberdade de imprensa; Debates sobre a criminalização da coleta de lenha caída.

${ }^{17}$ MÉSZÁROS, István. Filosofia, ideologia e ciência social. São Paulo: Boitempo, 2008, p. 158-161. Mas, assinale-se que, no conjunto do texto, o autor mencionado fica dividido acerca do problema pelo qual a crítica ao direito, feita por Marx, não seria uma crítica geral e sim dirigida a uma determinada forma como o direito se apresenta, o que achamos uma interpretação arbitrária do que Marx escreveu, notadamente em suas obras de maturidade.
} 
direito, naturais (sic) e imprescritíveis, a igualdade, liberdade, segurança e propriedade - estão, óbvio, subsumidos na crítica de Marx ao direito e, a rigor não deveria ser novidade e nem causar espanto, ele a ter submetido a uma desconstrução, para usar um termo caro aos chamados pósmodernos.

Marx nunca identificou sua crítica com a atitude dos conservadores que criticavam a declaração não pelo que ela tinha de limites e sim pela expressão, que ela era clara, da ascensão burguesa e da derrota da aristocracia feudal, a exemplo de Burke que considerava a declaração francesa insípida e a via enquanto fragmentos de papel exaltando supostos direitos do homem. Para ele, natural era, literalmente, "o respeito ao rei e o temor a deus" 18 .

Num outro campo, a crítica aos direitos humanos enquanto expressão da exaltação ao individualismo liberal então em ascensão era - e é - um chamamento à superação desses limites através da afirmação do humano enquanto ser coletivo e que só se afirma no coletivo, o qual, por sua vez é espaço de expressão, e não de tolhimento, de sua individualidade. A crítica restauracionista, a sua vez, o que criticava era a concessão de qualquer direito.

A visão liberal-individualista tenta, insistentemente, limitar as reivindicações dos direitos humanos ao terreno das garantias individuais, excluindo delas qualquer elemento da chamada "questão social", no que resultam os direitos humanos em meras garantias formais, como formal também é a moralidade burguesa - sem efetividade, e a serem imoladas eternamente no altar da vida real, que garante liberdade de opinião, direito de ir e vir, direito de propriedade e tanto mais, aos que não tem espaços midiáticos para opinar, não tem como sobreviver.

Bobbio, não obstante sua grandeza e honestidade intelectuais nem sempre se apercebe disso, notadamente quando oscila entre uma fundamentação historicamente constituída dos direitos humanos (pela qual não há busca de fundamento e que a busca do mesmo é infundada ${ }^{19}$ e a afirmação de um suposto caráter universal dos mesmos ${ }^{20}$.

Óbvio que o problema de tal distinção é que ela confunde questões de fato com questões de direito: meu "direito" a rebelar-se contra um Estado "injusto" independe de que esse Estado me "conceda" tal direito, isto é, que ela conste do ordenamento como garantia do cidadão, como, de fato, constou, nos primeiros momentos, da revolução francesa e americana. Ele é uma questão de fato, (embora alguns a tratem como questão moral) quer o Estado ou o Direito me

\footnotetext{
${ }^{18}$ BURKE, Edmund. Reflexões sobre a revolução em França. Brasília: UnB, 1982, p. 196.

${ }^{19}$ BOBBIO, Norberto. A era dos direitos. Rio de Janeiro: Elsevier, 2004, p. 37-38.

${ }^{20}$ Idem, p. 61, onde fala de uma pouco provável existência de "direitos absolutos".
} 
"dê" tal direito, quer não, visto que "força material só se enfrenta com força material”, na lição primorosa do próprio $\mathrm{Marx}^{21}$.

Sua consideração como questão moral é menos precária do que subsumi-la ao jurídico, que imagina que o direito à dissensão seria concessão jurídica. Embora incompreendida e/ ou distorcida, da crítica de Marx aos direitos humanos, pode-se perfeitamente - para demarcar-se dos que limitam as reivindicações sobre direitos humanos aos direitos individuais - lembrar-se da lição de Constant que, para criticar Rousseau, pediu licença e fez questão de ficar distante de filósofos reacionários que, por razões de classe disfarçadas de divergência intelectual, combatiam o grande genebrino.

É parafraseando Constant, que essa crítica, cujo referencial teórico é o de Marx, procura se situar, "evitando a companhia de detratores e quando parecer concordar com eles em qualquer ponto, desconfia de si mesma e que, para tranquilizar-se de, aparentemente, compartilhar de qualquer das opiniões deles, quer repudiar o mais possível essa pretensa colaboração". 22

Se examinada pelo contexto da existência, ou não, de suprafundamentos para o direito (o que inclui a ideia de um fundamento moral universal), a crítica aos direitos humanos enquanto universo limitado aos direitos formais para as maiorias e aos direitos individuais que, na maioria dos casos, só uma minoria, dotada de poder econômico, desfruta - notadamente no que concerne a apropriação privada - pode proporcionar mais fundamentação a uma reflexão acerca dos direitos humanos que possibilite sua concretização. Ora, a ideia, tipicamente jusnaturalista - de que haveria certos direitos superiores e anteriores a qualquer ordem jurídica - pode aparentemente fornecer um fundamento aos direitos humanos, mas deixa de fora uma questão: quem define esse "fundamento"?

Por outro lado esse modelo não nos livra, ao contrário, pode nos conduzir, a intolerância visto que estabelece um critério claramente eurocêntrico pelo qual as sociedades diferentes da nossa - indígena, islâmica, africana, afegã, iraquiana, iraniana, palestina etc - ao não respeitarem os direitos humanos (ou o que nossa cultura e nossa tradição entendem enquanto tal) seriam passíveis de punições e enquadramento, gerando o paradoxo pelo qual a violência seria meio garantidor da implantação de direitos humanos.

Enfrentar e tentar formular uma resposta, entre outras, passa a ser o objetivo da próxima

\footnotetext{
${ }^{21}$ MARX, Karl. A questão Judaica. São Paulo: Moraes, p. 117.

${ }^{22}$ Ver os termos da crítica de Constant à Rousseau, em: CONSTANT, Benjamin. Da liberdade dos antigos comparada à dos modernos. In: Revista Filosofia Política no. 2, 1985 . Disponível em: <http://www.caosmose.net/candido/unisinos/textos/benjamin.pdf>. Acesso em: 17/04/2009.
} 
parte

\section{A crítica de Marx à forma jurídica}

Marx, ainda que tivesse como objetivo político tardio a eliminação da forma jurídica enquanto manifestação de uma realidade alienada, nunca negou sua operacionalidade e inevitabilidade histórica nas sociedades marcadas pela luta de classes. Para ele, por "coerção externa" não se deve entender apenas a coerção estatal - baionetas e polícia - e sim as condições de vida material. As primeiras, longe de constituírem o fundamento da sociedade, são apenas exteriorizações da sua própria divisão ${ }^{23}$.

Ao criticar a concepção de direito de Hegel, Marx assinala que os erros deste advêm do fato de que:

Concebe [Hegel] as atividades estatais abstratamente, (...) e, por isso, em oposição à individualidade particular, esquecendo que tanto essa individualidade como as funções estatais são funções humanas. [...] Ele esquece que a essência da personalidade "particular" é a sua qualidade social e que funções estatais são modos de existência e de atividade das qualidades sociais. ${ }^{24}$

Perceber esses elementos ideológicos que permeiam o âmbito jurídico (e que visam justificar, em última instância, a manutenção do status quo) não significa necessariamente adesão a uma atitude de negação imediata do direito, com a consequente paralisia em relação à luta política concreta que se deve travar até a sua superação. Com isso, pode-se começar a antever que o fundamento da concepção marxista acerca do âmbito jurídico, que aqui se defende - da mesma forma no que concerne aos negócios morais - apoia-se num marco teórico que privilegia a ação humana enquanto práxis social e nela inclui o jurídico como categoria inserida na história, o que desloca qualquer ideia do direito como algo inerente ao ser humano.

Ora, a própria admissão do direito de propriedade privada como inerente ao ser humano, e não como resultado de um movimento histórico que, ao tempo em que abolia as relações feudais, criou outra forma de relação submissa (mais adequada ao novo paradigma da liberdade): o trabalho assalariado e venda das capacidades de cada um como se fosse uma

\footnotetext{
${ }^{23}$ MARX, Karl; ENGELS, Friedrich. A ideologia alemã. São Paulo: Boitempo, 2007, p. 462.

${ }^{24}$ MARX, Karl. Crítica da filosofia do direito de Hegel. São Paulo: Boitempo, 2005, p. 42, § $277 \beta$.
} 
mercadoria. Marx evidenciou a antinomia da inserção do direito de apropriação privada das riquezas sociais como um dos principais direitos humanos, oponível erga omnes, para aqui se usar uma expressão cara aos juristas, quando chamou atenção para o fato de que:

Se se entende que toda transgressão contra a propriedade é um roubo, não seria um roubo toda apropriação privada? Acaso minha propriedade privada não exclui a todo terceiro desta propriedade? Com isso, não lesiono, por consequência, o direito de propriedade dele? $?^{25}$

E diga-se desde logo que a crítica de Marx ao direito, e ao sentido de parte da teorização que dele se faz, tem como fundamento considerá-lo como manifestação de uma forma de vida alienada, na qual a forma jurídica e o Estado que lhe garante são apenas, do mesmo modo que a moral, modos particulares de expressão do movimento da produção e da alienação que dela resulta $^{26}$. E é este o aspecto fundamental da análise marxista, que aqui toma um dado concreto do âmbito jurídico: o seu uso enquanto discurso de justificação do poder e da solução controlada de conflitos que seu exercício permite, equilibrando coerção e consentimento ${ }^{27}$.

Óbvio que ao construir essa crítica à concepção burguesa de direitos humanos, Marx, em nosso ver, visava inviabilizar o discurso liberal, notadamente na justificação do direito de propriedade $^{28}$, cujo centro é a apropriação privada dos meios de produção, e que é a fonte fundamental das desigualdades sociais. Com isso, o sustentáculo de boa parte das ideias que fazem parte do senso comum jurídico e do compêndio de ilusões que ele constitui estaria solapado pela base.

No entanto, os que cindem, de um lado, a crítica à forma injusta de organização da sociedade, e a separam da concepção idealista que têm sobre o jurídico, acabam por se tornarem presa dessa visão parcial e acrítica do direito não conseguindo superar esse compêndio de ilusões. E não conseguem pelo motivo de que ou estão presas a ilusões referenciais, aderindo às crenças acerca do suposto caráter neutro do fenômeno jurídico ou, ainda, esperando do direito (do mesmo modo que da moral) uma racionalidade essencialista e previamente constituída, que a forma jurídica, como estrutura de justificação de decisões que visam neutralizar expectativas nem sempre prontas a serem atendidas, não pode oferecer. Essas ilusões também se sustentam

\footnotetext{
${ }^{25}$ MARX, Carlos. Los debates de la $6^{\text {a }}$ Dieta Renana sobre la ley castigando los robos de leña. In: Escritos de juventud. México: FCE, 1987, p. 248.

${ }^{26}$ MARX, Karl. Idem, ibidem, p. 19, 30, 39, 61, 106 e 130.

27 FEITOSA, Enoque. Estado e sociedade civil em Gramsci: entre coerção e consentimento. São Paulo: Malheiros, 2008, p. 367-392.

${ }^{28}$ MARX, Karl. Manuscritos econômico-filosóficos. São Paulo: Boitempo, 2005, p. 106.
} 
em termos vagos e genéricos, truísmos pouco discutidos e em favor dos quais há pouca simpatia de vê-los questionados, a exemplo da expressão "direito legítimo".

Parafraseando Marx, pode-se afirmar acerca do direito: os juristas nada mais fazem que a justificação do direito quando também importa entendê-lo em suas condicionantes sociais, o que cria as condições de pugnar por sua transformação. Mas, para realizar tal intento há que se ter, em relação ao âmbito jurídico uma única atitude científica possível (embora os juristas reivindiquem para o seu saber um status de ciência, eles quase que não adotam a atitude que aqui se propõe): um ceticismo esclarecido, ou mais simplesmente, um ceticismo metódico, o qual consiste em duvidar das obviedades e verdades "estabelecidas" e sagradas quanto ao direito, notadamente àquelas ditas eternas e imutáveis e que, não por coincidência, têm um papel regressivo, como, por exemplo, a justificação do direito de propriedade privada como parte dos direitos humanos, sem se dar conta, ou ocultando que, esse direito "erga omnes", que opõe o direito de seu titular contra todos os demais, isto é, contra toda sociedade, acaba por negar o direito da maioria em favor de uma minoria.

\section{O caráter classista do direito e da moral e a luta pela concretização dos Direitos Humanos}

Ora, na análise marxista do direito o que chama atenção é que, diferentemente das diversas formas de compreensão do jurídico - umas afirmando o direito como resultante de valores “intrínsecos”, pré-estabelecidos, a-históricos, acima e além de qualquer direito, situado antes mesmo e independente das necessidades concretas desse mundo - ela o vê como parte do movimento real da história humana e não enquanto dogmas elaborados de forma cerebrina, ou seja, afastada da vida social. ${ }^{29}$

Uma concepção historicamente situada, do direito - como assinalou Marx acerca do conjunto da atividade social, a moral aí inclusa -, só adquire potencial heurístico se e na medida em que reconhecer os indivíduos reais, sua ação e suas condições materiais de vida, tanto as já existentes como as resultantes de sua ação, pressupostos constatáveis, portanto, por via

\footnotetext{
${ }^{29}$ A célebre afirmação de Marx, já comentada neste excurso, pela qual "não há história do direito", poderia ser, equivocada ou interessadamente, esgrimida para negar o caráter histórico do fenômeno jurídico. Mas ela, para quem fundou o materialismo histórico, ou: a) é tomada como uma simples anotação para idéias a serem posteriormente desenvolvidas visto que, na mesma obra, Marx e Engels esboçam uma ... história do direito, ou, b) seria inteligível, na obra que funda o método histórico de Marx, no sentido de afirmar que não há história do direito, por que o direito está subsumido à história da luta de classes. Para essa questão, remeta-se, mais uma vez, para: MARX, Karl; ENGELS, Friedrich. A ideologia Alemã. São Paulo: Boitempo, 2007, p. 77, 330-331.
} 
empírica, o que não quer dizer que não possam ser abstraídos por necessidades metódicas ${ }^{30}$.

Assim, compreender o fenômeno jurídico demanda perceber que o ponto de partida não pode se limitar ao indivíduo isolado, ou seja, o sujeito imaginado pela concepção liberal das revoluções burguesas do século XIX, e sim o ser social porque o direito contemporâneo não pode olhar para trás e prescindir desses novos contextos. Ver o sujeito de direito como indivíduo - é assim na concepção liberal - e não como resultado histórico, constitui-se num erro metodológico de imaginar uma suposta produção desse indivíduo fora da coletividade. E não se constitui numa sólida compreensão do âmbito jurídico e da moralidade àquelas que ignoram (ou ocultam) como as diversas formas de relações de produção criam suas próprias formas de relações jurídicas e relações morais e que, por via reflexa, também ignoram a possibilidade de o direito se expressar como direito da força e mais: que tal forma não apenas se coaduna com um Estado de Direito como não lhe é conflitiva ${ }^{31}$. É preciso que se diga que não foi só no período da juventude de Marx que houve a preocupação de fundamentação do direito: em todas as ocasiões em que foi chamado a discutir os problemas que envolviam, em seu dizer, interesses materiais e em situações que demandavam o uso do raciocínio judicial, ele combinou a desmistificação da forma jurídica com uma refinada justificação interna, isto é, como teoria do direito e não teoria sobre o direito. Mas não caiu na armadilha da teoria do direito que apenas o justificasse.

O que nos conduz ao ponto essencial: $\mathrm{O}$ que os discursos sobre moral e direito buscam justificar? Se a resposta consistisse em afirmar que visam justificar suas próprias decisões e escolhas, ela levaria a um paradoxo pelo qual ao direito e a moral incumbiriam justificar o que já está decidido e, no caso da moral, escolhido. Note-se que o discurso moral não oculta esse aspecto de justificar o já escolhido. Curiosamente, o direito, que é uma instância coercitiva, não gosta de evidenciar essa inversão no que concerne a justificar o já decidido.

E ainda que parcialmente o direito faça isso - justifique o já determinado - é preciso que se diga que ele justifica o poder, que assim adquire a vaga qualidade de legítimo e, portanto, justifica a dominação, algo que a ideologia jurídica não admite, disfarçando o direito sob ideais vagos e genéricos como justiça, bem comum e paz social, valores a-históricos e cujo papel é apenas de justificação política-ideológica da forma jurídica. A luta pelos direitos humanos é a luta por sua concretização, é a luta para garantir os instrumentos de promoção da sociabilidade e não do isolamento e do egoísmo. Ser livre é ser plenamente senhor de si e isso só é possível

\footnotetext{
${ }^{30}$ MARX, Karl; ENGELS, Friedrich. A ideologia Alemã. São Paulo: Boitempo, 2007, p. 86-87.

${ }^{31}$ MARX, Karl. Para a crítica da economia política. São Paulo: Abril, 1978, p. 107.
} 
em sociedade que promova a vida em plenitude. A liberdade é uma palavra muito nobre para, em seu nome, se sancionar o egoísmo. Como Marx assinalou com agudeza, ninguém luta contra a liberdade em geral, no máximo se luta contra a liberdade dos outros a fim de se garantir um modelo egoístico de sociedade. É em razão disso que a experiência humana vivenciou os mais diversos tipos de liberdade, só que algumas como prerrogativas particulares ${ }^{32}$. Trata-se, portanto, de ampliá-las ao máximo, tornando-as não meras declarações formais e sim parte da vida concreta da sociedade humana, que só se emancipará plenamente quando não mais houver poucos com muito e muitos com nada.

Trata-se, por isso mesmo, de examinar as raízes filosóficas das tentativas de justificação da antinomia entre direitos sociais e apropriação privada das riquezas, o que se fará em seguida.

\section{Pode se falar numa justificação moral não-burguesa para o direito de propriedade privada? (duas concepções - jurídicas e morais - em confronto: direito de propriedade x função social da propriedade)}

Desde as antigas civilizações ficaram estabelecidos, em uma de suas variadas formas, determinados regimes de apropriação de bens, já a partir da sua forma mais antiga, a chamada propriedade da coletividade gentílica ${ }^{33}$. Nas formas coletivas de propriedade o que conta prioritariamente é a comunidade, constituída então como verdadeira unidade social, por conseguinte a terra pertence ao grupo social em sua totalidade e a propriedade privada se limita aos bens de uso pessoal.

Acerca dessas sociedades Marx já assinalava, em o capital ${ }^{34}$, que nas sociedades antigas não existia a propriedade privada da terra embora fosse reconhecido e aceito sua posse e uso, tanto privado quanto comum. Entre os gregos a propriedade privada se impõe lentamente e como consequência do surgimento da economia monetária, como atesta Aristóteles na "Ética a Nicômaco", quando aborda a questão da troca de equivalentes ${ }^{35}$. Antes, a propriedade tinha um caráter familiar. Anteriormente a proibição de testar havia sido abolida por Sólon já no início do século VI a.C.

\footnotetext{
${ }^{32}$ MARX, Karl. O debate da Dieta prussiana sobre a censura (Gazeta Renana, 12/05/1842). In: Liberdade de imprensa. Porto Alegre: L\&PM, 2001, p. 10

${ }^{33}$ ENGELS, Friedrich. A origem da família, da propriedade privada e do Estado. Rio de Janeiro: Civilização, 1979, p. 7 e 19.

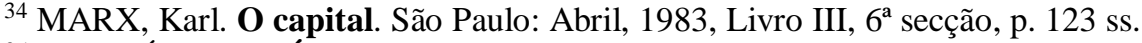

${ }^{35}$ ARISTÓTELES. Ética a Nicômaco. São Paulo: EMC, 2002, livro v, 5, 1133a25-30, p. 113-114.
} 
O uso da moeda teve efeitos antes inimaginados: a desigualdade na distribuição de riquezas aumentou imensamente, difundiu-se a hipoteca, a usura e a escravidão por dívidas. Em Roma embora não se tenha notícias de propriedade coletiva, sabe-se que o território de uma gens (ou tribo) era indiviso e a propriedade de coisas admitida tão somente para bens móveis e estava ligada a posse, sem a qual todo o direito a coisa desaparecia, isso dava a forma jurídica um caráter também moral. Só no período de Justiniano se consolida o direito de propriedade enquanto jus utendi et abutendi re sua (direito de uso e abuso de coisa própria, conforme as Pandectas).

Jurisdicizada plenamente a sociedade e institucionalizada, a partir da idade média, com o surgimento do comércio e da atividade bancária, além do completo regramento do direito de herança, o que demanda segurança jurídica e, posteriormente, com a justificação cristã, política e moral, do pleno de direito de propriedade voltado para os indivíduos e não mais para a coletividade, as formas de apropriação privada tornaram-se parte do senso comum e a defesa da propriedade coletiva algo estranho e herança bárbara. Ocorre que essa suposta defesa da propriedade coletiva enquanto "herança bárbara" omite o fato de que a institucionalização da propriedade privada se deu mediante uma violência contra a propriedade social ${ }^{36}$.

Na verdade, só com os iluministas, no século XVIII, ainda que de forma incipiente, e a ascensão das lutas sociais é que, tanto no âmbito jurídico como na história das ideias morais, a propriedade privada tende a começar a perder a condição de privilegio especial e da exclusiva e especial proteção que gozava. Com isso começa a se impor o conceito de que a propriedade de um bem será legitima tão somente se cumprir função social, isto é, se moralmente justificada. Assim, a propriedade sempre se constituiu num foco de tensões sociais, desestabilizando relações jurídicas e acirrando conflitos entre os indivíduos e entre estes e o Estado.

O ângulo de análise de Marx, eminentemente de classe, enfoca os direitos do homem em termos mais favoráveis e ainda que exponha com insuperável precisão o conteúdo burguês de tais direitos, oferece perspectivas de futuro ao denunciar a predominância do direito de apropriação privada em relação aos demais direitos. A questão, portanto, é: ao denunciar a propriedade privada enquanto limitação burguesa aos direitos do homem, Marx rechaçou a liberdade, o direito do povo de resistir à opressão? Ernst Bloch responde: evidentemente que não. Ao contrário, o propósito de Marx consistiu em fortalecer a ideia de liberdade e em

\footnotetext{
${ }^{36}$ Em uma passagem do livro I de "O capital", Marx examina as antinomias jurídicas acarretadas pelo intercâmbio de mercadorias e em que aponta, com agudeza, que "entre dois direitos iguais, decide a força". O capital, livro I. São Paulo, Abril, 1979, p.269.
} 
desenvolver suas consequências logicamente emancipadas completamente das travas da apropriação privada das riquezas sociais ${ }^{37}$.

Como a legislação deriva das pressões e conquistas sociais o que o próprio direito fez foi, pela pressão social, procurar criar instrumentos que regulassem os limites à apropriação privada, visando defender formas de propriedade reconhecidas no meio social e pacificar o conflito existente em torno delas. Veja-se o exemplo da ordem jurídica brasileira: de forma clara, o ordenamento jurídico pátrio só trata explicitamente da exigência de uma função social, a fim de legitimar o direito de propriedade, com a Constituição de 1988.

Tal instrumento visava, fundamentalmente, tanto ao enfrentamento do problema de extensas áreas urbanas sem uso algum e com finalidade apenas de formar estoques de terrenos com fins especulativos, mas, pelas características que conformaram a propriedade rural em nosso país, acabou por ter uma repercussão maior na discussão do direito de propriedade no campo.

Assim, o que se trata é que a sociedade brasileira edificou, indiscutivelmente, um novo padrão de justificação para o trato jurídico no que concerne a edificação de uma nova concepção de propriedade, que não pode mais ser vista como moralmente aceitável, separada de sua finalidade social. Como reconhecem boa parte dos estudiosos, existe no arsenal jurídico burguês todo um conjunto de regras - materiais e processuais - para a garantia e defesa da propriedade privada, que tem regime jurídico legal e constitucional que a defende.

Por isso que a tese especifica aqui defendida é a de que o problema da propriedade adquiriu um novo perfil e o campo de embate passou para a interpretação e aplicação não só da lei, mas de um embate entre moralidades de classe opostas, no trato da questão. Nublar tal problema só pode ser entendido enquanto ingenuidade ou opção ideológica disfarçada com argumentos jurídicos, como se verá a seguir.

\section{Conclusão: o fracasso (teórico) da tentativa liberal de compatibilizar duas exigências conflitantes}

Ao se estabelecer no caput do artigo quinto da atual Constituição brasileira, em sua parte final, ultima figura, que a propriedade constitui uma garantia individual inviolável se elevou o

\footnotetext{
${ }^{37}$ BLOCH, Ernst. El hombre e el ciudadano según Marx. In: Humanismo socialista. Buenos Aires: Paidós, 1974, p. 245.
} 
instituto da propriedade (propriedade como gênero, frise-se, já que ali não se estabelece proteção especifica a esse ou aquele tipo de propriedade) ao status de garantia fundamental. O erro das interpretações conservadoras - não por ignorância, mas por um ato de "hermenêutica interessada"38 - é que, para eles, essa elevação à garantia fundamental deve ser necessariamente interpretada como protegendo restritamente as formas privadas de propriedade. A propriedade - a não ser por ignorância ou má-fé - não pode mais ser vista nem como direito estritamente individual e nem mais como uma instituição puramente privada. Tal direito confere uma soberania relativa do indivíduo usar, fruir e dispor das comodidades e bens que legitimamente possuir.

Note-se que, na sua concepção originária, sob influência das revoluções burguesas, o direito de propriedade (sob um enfoque privatista) foi concebido como direito absoluto, erga ommnes, imprescritível e, para boa parte dos juristas, até como um direito natural, isto é, suprahumano. Tal o enfoque, por exemplo, da Declaração dos direitos do homem e do cidadão de 1789. Por isso Marx assinalaria, na esteira da tradição iluminista de Rousseau, que os direitos humanos, em oposição aos direitos do cidadão, são os direitos do homem individualista e egoísta e que a sociedade civil em que tais indivíduos viviam era o espaço do indivíduo egoísta ${ }^{39}$.

Para ele, o direito a apropriação privada tido como um direito que se opunha contra todos era um erro absurdo, político e lógico, pois na medida em que meu direito a algo se opõe contra qualquer um, eu estarei subtraindo desse algo a que ele tem também o direito de ter acesso $^{40}$, com o que a oposição ao direito de propriedade privada foi intuída por Rousseau no seu tratado sobre a origem das desigualdades quando ele afirma que aquele que teve, primeiro que todos, a ideia de cercar um lugar e dizer isto é meu, foi este indivíduo o verdadeiro inventor da sociedade civil ${ }^{41}$ até porque o direito à propriedade não pode ser superior, por exemplo, ao direito à vida, este efetivamente um direito constitucional fundamental ate mesmo porque

\footnotetext{
${ }^{38}$ Como já se teve oportunidade de abordar no corpo desta tese, no que seguimos Lukács, "a ação interessada é um componente essencial, substantivo, não eliminável, do ser social". LUKÁCS, György. Marx, Ontología del ser social. Madrid: Akal, 2007, p. 79. Aliás, o papel do interesse já fora localizado por Marx e Engels: "Se o interesse é o princípio de toda moral, então o que importa é que o interesse privado coincida com o interesse humano". MARX, Karl; ENGELS, Friedrich. A sagrada família. Lisboa: Presença, 1974, p. 196.

${ }^{39}$ MARX, Karl. Critica filosofia do direito de Hegel (Introdução). São Paulo: Cortez, 1995, p. 17.

${ }^{40}$ MARX, Karl. Sobre a questão da criminalização da coleta de lenha caída. In: Escritos de Juventude. São Paulo: Vitoria, 1958, p. 37-52 e, no que concerne ao debate ao moral: Observaciones sobre la reciente reglamentación de la censura prusiana (por un rinlandés). In: Escritos de juventud sobre el derecho. Barcelona: Antrophos, 2008, p. 64.

${ }^{41}$ ROUSSEAU, Jean-Jacques. Discurso sobre a origem das desigualdades entre os homens. São Paulo: Abril, 1983 , p. 89.
} 
explica, em grau próximo ou remoto a existência dos demais direitos ${ }^{42}$.

Nesse terreno, do direito de propriedade, as observações de Marx também criticaram o entendimento da economia e da história pela moral porque, segundo ele mesmo afirma, em carta escrita em setembro de 1843, para Ruge, o avanço dessa nova concepção consiste exatamente em não antecipar dogmaticamente o mundo, mas, apontar o novo, através da crítica do velho ${ }^{43}$.

\section{Referências}

ARISTÓTELES. Ética a Nicômaco. São Paulo: EMC, 2002

BLOCH, Ernst. El hombre y el ciudadano según Marx. In: Humanismo socialista. Buenos Aires: Paidós, 1974

BOBBIO, Norberto. Marx e a teoria do direito. In: Nem com Marx, nem contra Marx. São Paulo: UNESP, 2006

A era dos direitos. Rio de Janeiro: Elsevier, 2004

BURKE, Edmund. Reflexões sobre a revolução em França. Brasília: UnB, 1982

CONSTANT, Benjamin. Da liberdade dos antigos comparada à dos modernos. In: Revista Filosofia Política no. 2, 1985.

COSSÍO DIAZ, José Ramon. Derecho y análisis económico. Mexico: FCE, 2001

ENGELS, Friedrich. A origem da família, da propriedade privada e do Estado. Rio de Janeiro: Civilização, 1979

FEITOSA, Enoque. Estado e sociedade civil em Gramsci: entre coerção e consentimento. São Paulo: Malheiros, 2008

FRANCA, V. R. Função social da propriedade na Constituição Federal. In: Revista Jurídica da UFRN. Natal, 1995

HART, Herbert. O conceito de direito. Lisboa: Calouste Gulbenkian, 2005.

KELSEN, Hans. Teoria pura do direito. Lisboa: Armênio Amado, 1979

LUKÁCS, György. Marx, Ontología del ser social. Madrid: Akal, 2007

LUX, K. Adam Smith's mistake: How a moral philosopher invented Economics and endend 
morality. Boston: Shambhala Publications, 1990

LYRA FILHO, Roberto. Karl, meu amigo: Diálogo com Marx sobre o direito. Porto Alegre: SAFE / IARS, 1983

MARX, Karl. The nationalisation of the land. In: Marx and Engels Collected Works. Vol. 23. London: Lawrence \& Wishart, 2010

. Para a questão Judaica. São Paulo: Expressão Popular, 2009

Observaciones sobre la reciente reglamentación de la censura prusiana (por un rinlandés). In: Escritos de juventud sobre el derecho. Barcelona: Antrophos, 2008

. Manuscritos econômico-filosóficos. São Paulo: Boitempo, 2005

Crítica da filosofia do direito de Hegel. São Paulo: Boitempo, 2005

A sagrada família. São Paulo: Boitempo, 2003

O debate da Dieta prussiana sobre a censura (Gazeta Renana, 12/05/1842). In:

Liberdade de imprensa. Porto Alegre: L\&PM, 2001

Letters: Marx and Ruge. In: Writings of the young Marx on Philosophy and society. Indianapolis: Hackett Publishing, 1997

. Critica filosofia do direito de Hegel (Introdução). São Paulo: Cortez, 1995

Grundrisse: Elementos fundamentales para la crítica de la economía política. México: siglo XXI, 1989

Escritos de juventud. México: FCE, 1987

. O capital. São Paulo: Abril Cultural, 1983

Para a crítica da economia política. São Paulo: Abril, 1978

Crítica ao Programa de Gotha. São Paulo: ES, 1977

A questão Judaica. São Paulo: Moraes, 1977

MARX, K.; ENGELS, Friedrich. German ideology. In: Marx \& Engels Collected works, vol.5 (Marx and Engels 1845-47). London: Lawrence and Wishart, 2010

A ideologia Alemã. São Paulo: Boitempo, 2007

A sagrada família. Lisboa: Presença, 1974

MARSILAC, Narbal de. A relegitimação da retórica e os direitos fundamentais do homem. In: Verba Júris (Anuário da Pós-Graduação em Direito), ano 7, nº . 7. João Pessoa: UFPB / CCJ / 
PPGCJ, 2008, p. 35-52

MÉSZÁROS, István. Filosofia, ideologia e ciência social. São Paulo: Boitempo, 2008

NAVES, Márcio. Direito e transição socialista. In: Práxis. Ano 4, nº ${ }^{\circ}$ 10. Belo Horizonte: Projeto, 1997

ROSS, Alf. Direito e Justiça. São Paulo: Edipro, 2007

ROUSSEAU, Jean-Jacques. Discurso sobre a origem das desigualdades entre os homens. São Paulo: Abril, 1983 